\title{
Narcine atzi Carvalho \& Randall, 2003 (Pisces: Narcinidae) - an addition to Indian ichthyofauna
}

\author{
K. SUJATHA, V. A. ISWARYA DEEPTI, V. RAVALI AND SNEHA JHA \\ Department of Marine Living Resources, Andhra University, Visakhapatnam - 530 003, Andhra Pradesh, India \\ e-mail:sujatha.mlr@gmail.com
}

\begin{abstract}
A species of electric ray of family Narcinidae, Narcine atzi Carvalho \& Randall, 2003 has been recorded for the first time from Indian waters. Five specimens of $N$. atzi in the length range of $343-415 \mathrm{~mm}$ (TL) were collected from demersal shrimp trawl catches at Visakhapatnam, central eastern coast of India. The present paper provides description on morphometric characters of the species along with a comparative account on earlier descriptions.
\end{abstract}

Keywords: Description, First record, Indian waters, Narcine atzi, Numb fish

In recent years, various revision studies on electric rays revealed that some genera are more diverse than previously understood (Carvalho et al., 2000). Twenty species of small to medium-sized batoids belonging to the genus Narcine Henle, 1834 (numbfishes) of the order Torpediniformes (Carvalho and Randall, 2003) are distributed in the tropical Indo-west Pacific region.

Day (1878) described one species Narcine timlei under the family Torpedinidae in Indian waters. Munro (1955) reported two species viz., Narcine brunnea and N. timlei and Sujatha (2002) provided key to three species viz., N. brunnea, Narcine maculata and N. timlei from Visakhapatnam waters. Akhilesh et al. (2014), reported six species of genus Narcine (N. brunnea, N. lingula, $N$. prodorsalis, $N$. timlei, $N$. oculifera and $N$. maculata) and one species of genus Benthobatis in the family Narcinidae from Indian waters in their updated checklist of Chondrichthyans. In addition to the above six species under the genus Narcine that are reported from Indian waters, the present study reports for the first time, one more species Narcine atzi Carvalho and Randall, 2003, a new numb fish hitherto unknown from Indian waters, from the trawl catches of Visakhapatnam region. As per IUCN Red List, this species is assessed as 'data deficient' (DD) (Carvalho and McCord, 2009). The present paper provides detailed description of this species.

Samples were collected during May to August 2015, from Visakhapatnam Fisheries Harbour where catches from nearby fish landing centres are also brought for sale. Visakhapatnam coast is known for its rocky habitats and their associated fish species. Commercial trawlers fish within $17^{\circ} 10^{\prime}-18^{\circ} 10^{\prime} \mathrm{N}$ and $82^{\circ} 50^{\prime} \mathrm{E}$ to $84^{\circ} 10^{\prime} \mathrm{E}$ that extends from Kakinada in the south to Gopalpur in the north, in the depth range between 30-220 m along east coast of India. The total length (TL) of the specimens was taken from tip of snout to caudal fin tip and measured to nearest $\mathrm{mm}$. Identification of specimens, descriptions and terminology for morphometric characters follow Carvalho et al. (2002) and Compagno and Heemstra (2007). External and morphometric measurements were taken following Bigelow and Schroeder (1953).

Five specimens of $N$. atzi (length range 343-415 mm TL) were collected from trawl catches of Visakhapatnam, of which there were three females and two males.

Taxonomic and morphometric details

Class : Chondrichthyes

Order : Torpediniformes

Family : Narcinidae

Genus : Narcine Henle, 1834

Narcine atzi Carvalho and Randall, 2003

Fig. 1, Table 1

Narcine atzi Carvalho and Randall, 2003

Narcine atzi Carvalho and Randall, 2003, Ichthyol Res., 50: 59-66 (Type Locality: Oman, Arabian Sea)

Common name - Atz's numb fish

Diagnostic characters: Disc subovate, eyes smaller than spiracles. Interspiracular distance lesser than interorbital distance. Gill slits with small central lobe extending backwards. Mouth width more than internarial width. Pre-orbital snout length greater than pre-nasal snout length. Pelvic fins originate ventral to insertion of posterior disc margins. Origin of first dorsal fin anterior to level of pelvic fin insertion. 


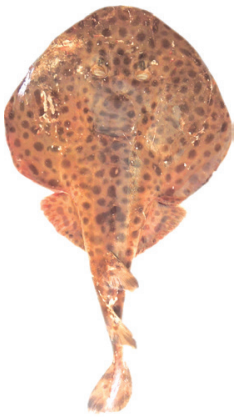

(a)

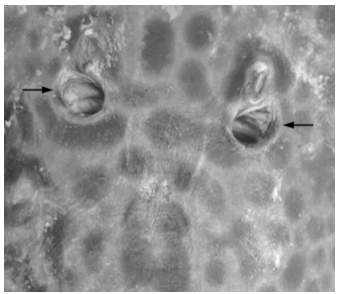

(e)

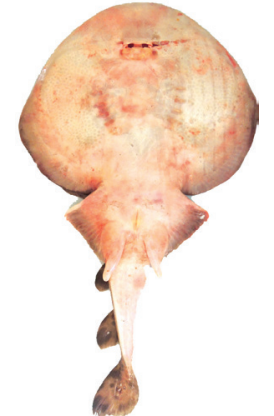

(b)

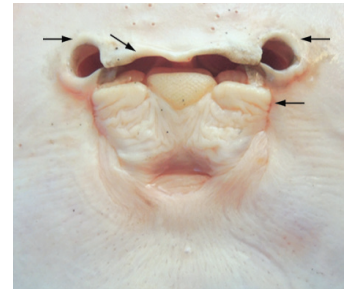

(f)

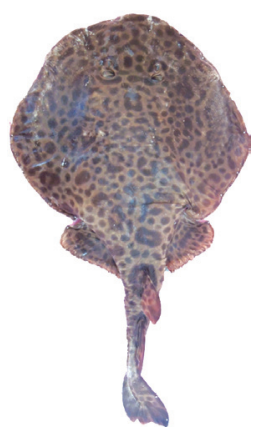

(c)

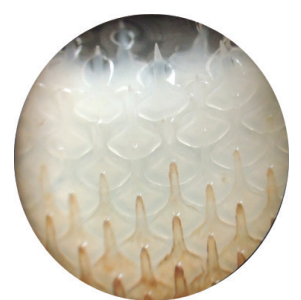

(g)

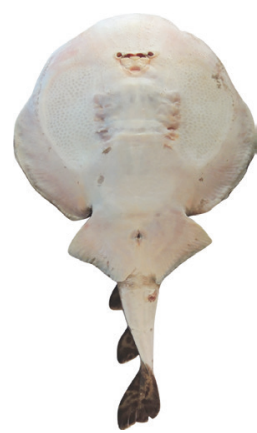

(d)

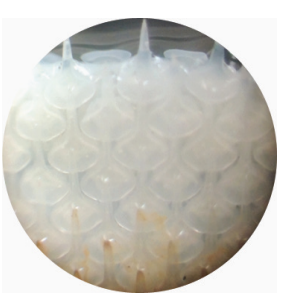

(h)

Fig. 1. Narcine atzi Carvalho \& Randall, 2003

(a) Dorsal view (343 mm - male), (b) Ventral view (343 mm - male), (c) Dorsal view (407 mm - female), (d) Ventral view (407 mm - female), (e) Eyes and spiracles showing spots in the spiracular walls, (f) Mouth and nostrils, (g) Upper tooth band (showing cusps), (h) Mandibular tooth band

Colour: Arrangement of spots follow a pattern where a single larger spot is encircled by seven to eight spots. Some spots are isolated, rounded to oval and some fused forming vermiculations. Spots present within the spiracular walls. Large rounded blotches encircle the two dorsal fin bases.

Description: Disc sub-ovate and broadly wide, slightly posterior to its mid length. Head broad and depressed. Snout rounded and broad (Fig. 1a, c). Eyes oval, dorsolateral, partially medial and anterior to spiracles. Spiracles just behind the orbits; spiracles subcircular, broad and distinguished with elevated borders, width measuring more than length (Fig. 1e). Interspiracular distance lesser than interorbital distance. Gill slits wide, distance between the gill slits gradually decreases from first to fifth gill slits (Table 1); gill slits with small central lobe extending backwards. A pair of large kidney-shaped electric organs rests on pectoral fins which are visible through skin emerging from the level of nostrils and spread till the fifth gill slits (Fig. 1b, d). Mouth length wider than internarial width (Fig. 1f). Tooth bands broad, much wider than long; tooth bands on both the jaws with cuspidate teeth, equal in size; teeth numerous with nearly flat base with long and pointed cusp; out of 26 and 25 rows of teeth, 11 rows with prominent cusps (Fig. 1g, h). Anterior rows of teeth remain exposed when the mouth is closed and these teeth with worn down and short cusps. Nostrils circular, posterior border slightly elevated. Anterior nasal flaps short but medially expanded and fused into a broad nasal curtain. Nasal curtain not covering the upper exposed tooth band; few sensory pores present around the mouth and nostrils (Fig. 1f). Pre-orbital snout length greater than pre-nasal snout length. Pectoral fins originating at anterior edge of snout lateral to snout tip, attached to head and ending opposite to the origin of pelvic fins. Pelvic fins originate ventral to insertion of posterior disc margins, extends posteriorly to two thirds of first dorsal fin base. In males, the posterior lobes of the pelvic fins are straight leaving a small free lobe near the attachment to the claspers, whereas in females it is on the lateral sides of the trunk. Calcified claspers extending beyond the pelvic fins were observed in the two sexually mature male specimens in the present study. Origin of first dorsal fin anterior to level of pelvic fin insertion. Distal part of first dorsal fin rounded; second dorsal fin slanted with acute apex. Distance between second dorsal and caudal fin lesser than interdorsal space. Tail moderately stout at base. Prominent flap-like ventro-lateral tail folds originates in between first and second dorsal fins extending posterior to caudal peduncle. Caudal fin asymmetrical.

Colour : Disc brown dorsally, with close set of dark brown spots distributed all over the disc which vary in size (equal to or smaller than eye diameter). The arrangement of spots follows a pattern where a single larger spot is encircled by seven to eight spots. Some spots are isolated, rounded to oval and some fused forming vermiculations. Spots present within spiracular walls. Small spots present on dorsal and 
Table 1. Morphometric comparisons of Narcine atzi, expressed as \% of total length (TL)

\begin{tabular}{|c|c|c|c|c|c|c|}
\hline \multicolumn{3}{|l|}{$\begin{array}{l}\text { Narcine atzi } \\
\text { TL }(\mathrm{mm}) 343-415, \mathrm{n}=5, \widehat{\jmath}=2(\mathrm{TL} \\
343,389) ; \uparrow=3(\mathrm{TL} 365,407,415)\end{array}$} & \multicolumn{4}{|c|}{$\begin{array}{l}\text { Carvalho and Randall (2002) Narcine atzi } \mathrm{n}=5 \text {, } \\
\text { CAS } 58398 \text { (Srilanka), CAS 98157(Myanmar); } 3 \text { pups }(107-113 \mathrm{~mm} \\
\text { TL) data same as holotype. Mean and SD based on all specimens }\end{array}$} \\
\hline & & & Holotype & CAS 58398 & CAS 98157 & \multirow{2}{*}{ Mean \pm S.D } \\
\hline Measurements & Range & Mean \pm SD & $\% \mathrm{TL}$ & $\% \mathrm{TL}$ & $\% \mathrm{TL}$ & \\
\hline Disc width & $47.40-55.39$ & $50.91 \pm 3.16$ & 58.4 & 53.7 & 52.2 & $54.8 \pm 3.2$ \\
\hline Disc length & $42.41-47.17$ & $44.70 \pm 2.08$ & 54.2 & 47.0 & 50.0 & $50.4 \pm 3.6$ \\
\hline Snout length & $11.57-13.02$ & $12.14 \pm 0.56$ & - & - & - & - \\
\hline Snout, pre-orbital & $11.81-12.60$ & $12.26 \pm 0.33$ & 12.8 & 10.9 & 12.6 & $12.1 \pm 1.1$ \\
\hline Snout, pre-oral & $11.81-13.27$ & $12.61 \pm 0.53$ & 14.1 & 15.3 & 15.3 & $14.9 \pm 0.7$ \\
\hline Snout, pre-nasal & $11.51-12.53$ & $11.87 \pm 0.43$ & 7.1 & 10.2 & 12.0 & $9.8 \pm 2.5$ \\
\hline Eye diameter & $1.37-1.97$ & $1.61 \pm 0.24$ & 2.6 & 3.2 & 2.6 & $2.8 \pm 0.3$ \\
\hline Interorbital distance & $6.71-7.47$ & $7.12 \pm 0.33$ & 5.9 & 6.8 & 6.0 & $6.2 \pm 0.5$ \\
\hline Spiracle length & $1.97-2.57$ & $2.24 \pm 0.26$ & 2.8 & 2.6 & 2.3 & $2.5 \pm 0.3$ \\
\hline Spiracle width & $2.74-3.21$ & $2.92 \pm 0.18$ & 3.3 & 3.4 & 2.9 & $3.2 \pm 0.3$ \\
\hline Interspiracular distance & $5.75-6.88$ & $6.03 \pm 0.48$ & 5.3 & 5.8 & 5.1 & $5.4 \pm 0.4$ \\
\hline Orbit \pm spiracle length & $4.08-4.67$ & $4.31 \pm 0.24$ & - & - & - & - \\
\hline Pectoral base & $38.56-40.79$ & $39.65 \pm 1.04$ & - & - & - & - \\
\hline $1^{\text {st }}$ Dorsal height & $7.71-10.07$ & $9.22 \pm 0.92$ & 11.3 & 11.6 & 9.8 & $10.9 \pm 1.0$ \\
\hline $1^{\text {st }}$ Dorsal base length & $6.94-7.87$ & $7.42 \pm 0.37$ & 8.5 & 7.6 & 6.4 & $7.5 \pm 1.0$ \\
\hline $2^{\text {nd }}$ Dorsal height & $8.74-10.50$ & $9.75 \pm 0.71$ & 8.9 & 9.6 & 8.5 & $9.0 \pm 0.6$ \\
\hline $2^{\text {nd }}$ Dorsal base length & $7.47-8.45$ & $7.99 \pm 0.35$ & 7.3 & 5.8 & 5.6 & $6.2 \pm 0.9$ \\
\hline Interdorsal space & $3.86-4.96$ & $4.45 \pm 0.40$ & 5.9 & 7.4 & 6.6 & $6.6 \pm 0.8$ \\
\hline $2^{\text {nd }}$ Dorsal to upper caudal distance & $3.56-5.14$ & $4.12 \pm 0.65$ & 6.4 & 6.8 & 6.8 & $6.7 \pm 0.2$ \\
\hline Caudal height upper lobe & 14.91-18.92 & $17.05 \pm 1.67$ & 15.7 & 15.2 & 14.6 & $15.2 \pm 0.6$ \\
\hline Caudal height lower lobe & $12.08-14.50$ & $13.64 \pm 0.96$ & 13.4 & 13.8 & 14.8 & $14.0 \pm 0.7$ \\
\hline Caudal margin length & $9.25-12.04$ & $10.03 \pm 1.14$ & - & - & - & - \\
\hline Tail height at caudal origin & $2.46-3.08$ & $2.82 \pm 0.24$ & - & - & - & - \\
\hline Tail width at caudal origin & $2.57-2.74$ & $2.66 \pm 0.07$ & - & - & - & - \\
\hline Lateral tail fold length & $20.64-24.94$ & $22.45 \pm 1.90$ & - & - & - & - \\
\hline Head length; ventral & $30.60-33.42$ & $31.79 \pm 1.07$ & - & - & - & - \\
\hline Head length; dorsal & 18.31-19.66 & $18.82 \pm 0.60$ & - & - & - & - \\
\hline Mouth width & $4.63-5.90$ & $5.20 \pm 0.47$ & 7.0 & 7.3 & 7.1 & $7.1 \pm 0.2$ \\
\hline Upper tooth band width & $2.31-3.01$ & $2.51 \pm 0.29$ & 2.9 & 2.6 & 1.8 & $2.4 \pm 0.6$ \\
\hline Lower tooth band width & $2.31-3.01$ & $2.51 \pm 0.29$ & 2.6 & - & 1.5 & $2.0 \pm 0.8$ \\
\hline Internarial width & $4.93-5.54$ & $5.22 \pm 0.25$ & 4.6 & 5.0 & 5.1 & $4.9 \pm 0.2$ \\
\hline Nasal cut length & $1.45-4.96$ & $2.42 \pm 1.43$ & 2.2 & 2.1 & 1.6 & $2.0 \pm 0.3$ \\
\hline Nasal curtain width & $4.66-5.83$ & $5.27 \pm 0.43$ & 4.5 & 4.8 & 5.6 & $5.0 \pm 0.5$ \\
\hline $1^{\text {st }}$ gill slit length & $1.80-2.70$ & $2.39 \pm 0.39$ & - & - & - & - \\
\hline $3^{\text {rd }}$ gill slit length & $2.06-3.44$ & $2.80 \pm 0.53$ & - & - & - & - \\
\hline $5^{\text {th }}$ gill slit length & $1.54-2.47$ & $2.12 \pm 0.44$ & - & - & - & - \\
\hline Space between $1^{\text {st }}$ gill slits & $12.34-14.52$ & $13.88 \pm 0.92$ & 13.6 & 14.0 & 15.3 & $14.3 \pm 0.9$ \\
\hline Space between $3^{\text {rd }}$ gill slits & $10.03-12.60$ & $11.90 \pm 1.07$ & - & - & - & - \\
\hline Space between $5^{\text {th }}$ gill slits & $8.23-10.81$ & $9.42 \pm 0.92$ & 7.5 & 8.8 & 8.6 & $8.3 \pm 0.7$ \\
\hline Pelvic fin length & 16.14-18.08 & $16.56 \pm 0.85$ & 21.3 & 16.3 & 16.7 & $18.1 \pm 2.8$ \\
\hline Pelvic fin width & $14.40-18.37$ & $17.07 \pm 1.56$ & 39.0 & 34.2 & 33.6 & $35.6 \pm 3.0$ \\
\hline Pelvic fin end to $1^{\text {st }}$ dorsal origin & $6.30-7.62$ & $6.86 \pm 0.49$ & & & & - \\
\hline Anterior margin of pelvic fin & $9.25-10.81$ & $10.10 \pm 0.58$ & 13.5 & 11.3 & 12.3 & $12.4 \pm 1.1$ \\
\hline Posterior margin of pelvic fin & $13.70-18.08$ & $16.37 \pm 1.62$ & 17.7 & 16.1 & 17.9 & $17.2 \pm 1.0$ \\
\hline Snout to pelvic origin & $43.15-46.68$ & $44.91 \pm 1.54$ & - & - & - & - \\
\hline Snout to mid of cloaca & 49.87-52.09 & $51.10 \pm 0.93$ & 53.2 & 51.7 & 50.0 & $51.6 \pm 1.6$ \\
\hline Snout to $1^{\text {st }}$ dorsal origin & $58.02-60.27$ & $59.39 \pm 0.89$ & 60.0 & 58.1 & 55.6 & $57.9 \pm 2.3$ \\
\hline Snout to $2^{\text {nd }}$ dorsal origin & $71.14-72.33$ & $71.85 \pm 0.57$ & - & - & - & - \\
\hline Snout to maximum disc width & $35.48-39.07$ & $37.19 \pm 1.47$ & 24.2 & 26.2 & 30.6 & $27.0 \pm 3.3$ \\
\hline Snout to $1^{\text {st }}$ gill slit & $22.41-25.55$ & $23.70 \pm 1.15$ & - & - & - & - \\
\hline Mid of cloaca to tail end & $49.40-51.60$ & $50.45 \pm 0.78$ & 47.1 & 47.7 & 47.2 & $47.3 \pm 0.3$ \\
\hline Electric organ length & $20.96-23.01$ & $22.18 \pm 0.80$ & 24.5 & 22.8 & 21.1 & $22.8 \pm 1.7$ \\
\hline Electric organ greatest width & $9.86-14.25$ & $11.86 \pm 1.67$ & 12.3 & 9.4 & 9.7 & $10.5 \pm 1.6$ \\
\hline Electric organ width at $1^{\text {st }}$ gill slit & $9.86-11.79$ & $10.46 \pm 0.79$ & - & - & - & - \\
\hline Clasper length & $3.56-3.79$ & $3.65 \pm 0.09$ & - & - & - & - \\
\hline Clasper outer length & $11.30-12.54$ & $11.70 \pm 0.51$ & - & - & - & - \\
\hline Clasper-cloaca length & $12.04-13.41$ & $12.33 \pm 0.61$ & - & - & - & - \\
\hline Maximum tail width at pelvic fin & $15.17-19.41$ & $17.67 \pm 1.76$ & 18.6 & 18.7 & 16.4 & $17.9 \pm 1.3$ \\
\hline Cloaca length & $3.60-4.91$ & $4.36 \pm 0.54$ & - & - & - & - \\
\hline
\end{tabular}


caudal fins. Ventral colouration uniform white but edges of disc and pelvic fin margins grey. Two to three rows of spots present on ventral fins. Large rounded blotches encircle the two dorsal fin bases. Single large spot present towards edges of dorsal fins and caudal fin and a crescent shaped spot present on the two dorsal fin bases.

Morphometric data of present specimens of Narcine atzi are in agreement with Carvalho and Randall (2003), who observed that the first dorsal fins are clearly taller than second dorsal fin and pre-orbital snout length is not as great as pre-oral snout length. In the present specimens, second dorsal equal to or slightly taller than first dorsal fin and pre-orbital snout length equal to or not as great as pre-oral snout length (Table 1).

Narcine atzi can be distinguished from other closely resembling species of the genus Narcine of this region on the basis of disc shape, origin of dorsal fins and colour pattern. Disc: Sub ovate in N. atzi vs oval in $N$. lingula, subovate in $N$. indica and $N$. maculata, shovel shaped in $N$. prodorsalis, First dorsal fin origin: anterior to level of pelvic fin insertion in $N$. atzi vs posterior to pelvic fin insertion in $N$. lingula, $N$. indica; opposite to pelvic fin insertion in N. maculata, $N$. prodorsalis Colour pattern: Dorsal surface with a few spots fused forming vermiculations in $N$. atzi vs a few spots fused forming pear shaped markings in N. lingula; a few elongated chocolate brown spots in $N$. indica; large rounded dark brown spots in N. maculata; a few circular spots fused in N. prodorsalis. Spiracle: Spots present within the spiracular walls in $N$. atzi vs spots not present in the spiracular walls in $N$. lingula, $N$. indica, $N$. maculata and $N$. prodorsalis.

Numbfishes are circumglobal in distribution and occur on upper continental slopes, from the intertidal down to depths of 1,071 m (Carvalho et al., 2000). N. atzi was reported from Gulf of Oman, SriLanka and Myanmar by Carvalho and Randall (2003). This is the first record of this species from Indian waters. During recent years, at Visakhapatnam, vessels extended operation of trawl nets deeper into the sea (even upto 200-300 m) bringing in more varieties of demersal fishes that include numb fishes. A wide variety of these species are occurring in the catches ever since the extension of fishing operations to deeper waters.

\section{Acknowledgements}

The authors thank the Head, Department of Marine Living Resources, Andhra University for providing facilities to carryout the research work. The authors are thankful to Ministry of Earth Sciences (MoES) - Centre for Marine Living Resources and Ecology (CMLRE),
Kochi for financial support under ITIS project. First three authors are thankful to University Grants Commission (UGC), New Delhi for fellowships.

\section{References}

Akhilesh, K. V., Bineesh, K. K., Gopalakrishnan, A., Jena, J. K., Basheer, V. S. and Pillai, N. G. K. 2014. Checklist of Chondrichthyans in Indian waters. J. Mar. Biol. Ass. India, 56: $109-120$.

Bigelow, H. B. and Schroeder, W. C. 1953. The fishes of the western north Atlantic, Part II: Saw fishes, Skates, Rays and Chimaeroids. Mem. Sears Foundation. Mar. Res. 2: $1-58$.

Carvalho, M. R. de and McCord, M. E. 2009. Narcine atzi. The IUCN Red List of Threatened Species 2009: e.T161660A5474871. http://dx.doi.org/10.2305/IUCN.UK.20092.RLTS T161660A5474871.en. (Accessed 20 September 2016).

Carvalho, M. R. de and Randall, J. E. 2003. Numb fishes from the Arabian Sea and surrounding gulfs, with the description of a new species from Oman (Chondrichthyes: Torpediniformes: Narcinidae). Ichthyol. Res., 50: 59-66.

Carvalho, M. R. de, Compagno, L. J. V. and Last, P. R. 2000 Family Narcinidae. In: Carpenter, K. E. and Niem, V. (Eds.), FAO species identification guide for fisheries purposes. The living marine resources of Western Central Pacific. FAO Rome, p. 1432-1442.

Carvalho, M. R. de, Compagno, L. J. V. and Mee, J. K. L. 2002a. Narcine oculifera: a new species of electric ray from the gulfs of Oman and Aden (Chondrichthyes: Torpediniformes: Narcinidae). Copeia, 2002: 137-146.

Carvalho, M. R. de, Seret, B. and Compagno, L. J. V. 2002. A new species of electric ray of the genus Narcine Henle, 1834 from the south western Indian Ocean (Chondrichthyes: Torpediniformes: Narcinidae). South African J. Mar. Sci., 24: $135-149$

Compagno, L. J. V. and Heemstra, P. C. 2007. Electrolux addisoni, a new genus and species of electric ray from east coast of South Africa (Rajiformes: Torpedinoidei: Narkidae) with a review of torpedinoid taxonomy. Smith Bull., 7: 15-49.

Day, F. 1878. The fishes of India; being a natural history of the fishes known to inhabit the seas and freshwaters of India, Burma and Ceylon. Vol. 1 and 2. Dawson and Sons, London, $778 \mathrm{pp}$.

Henle, F. G. J. 1834. Ueber Narcine, eine neue Gattung electrischer Rochen nebst einer Synopsis der electrischen Rochen, Berlin, 44 pp.

Munro, I. S. R. 1955. The marine and freshwater fishes of Ceylon. Department of External Affairs, Canberra, $351 \mathrm{pp}$.

Sujatha, K. 2002. Batoid fishes off Visakhapatnam, north-east coast of India. J. Mar. Biol. Ass. India, 44: 155-162. 